Plicase sution 


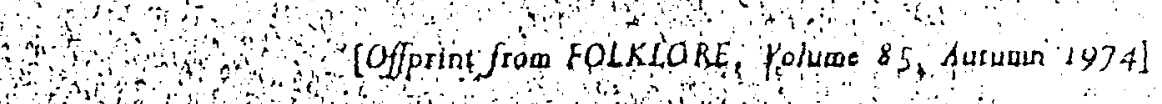

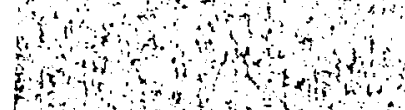

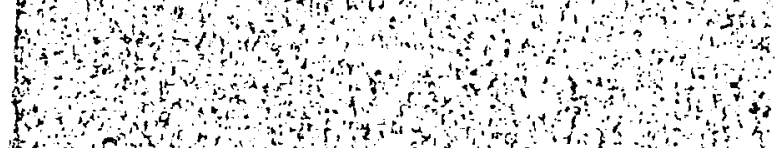

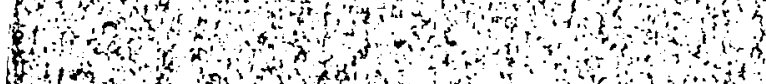

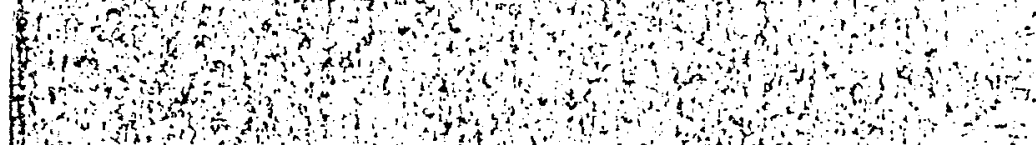

WH Interpretation of the Role Wof the Hoopoe in Afgh
Folklore and Magic

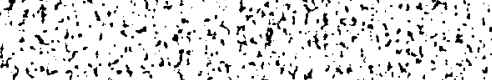
nom, to

(th

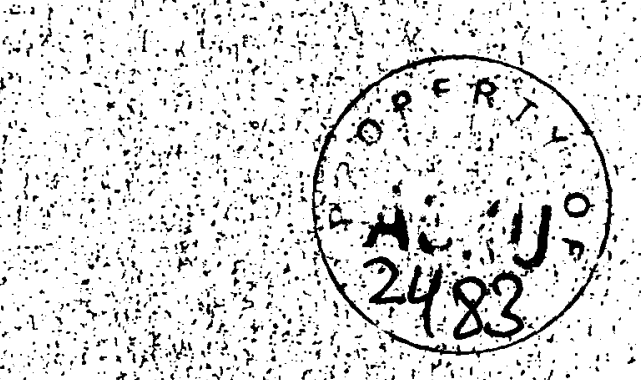


A

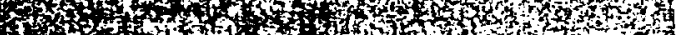

3
4 130.

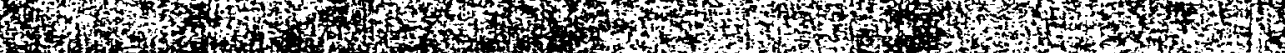
(x)

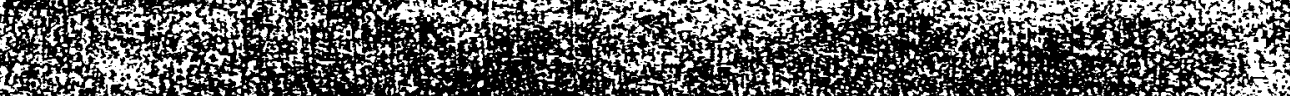

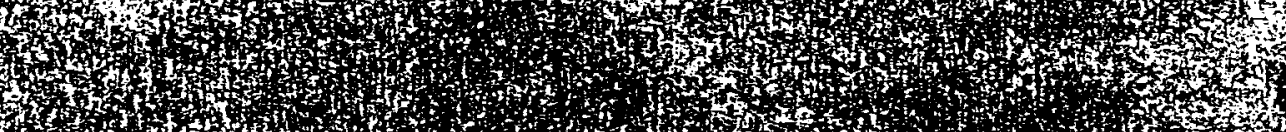

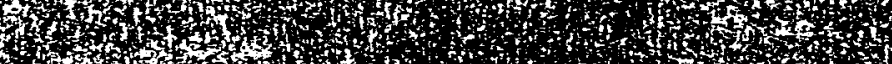

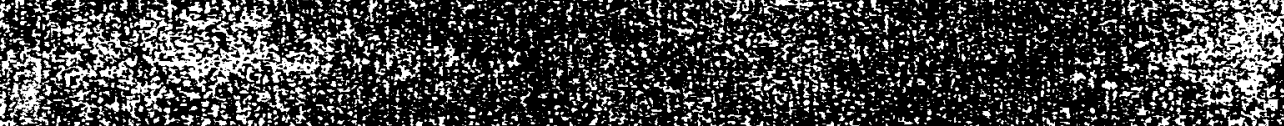

How

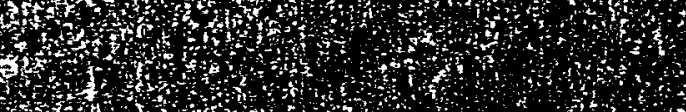

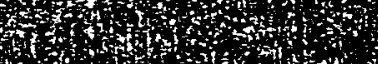

(3) 30,0

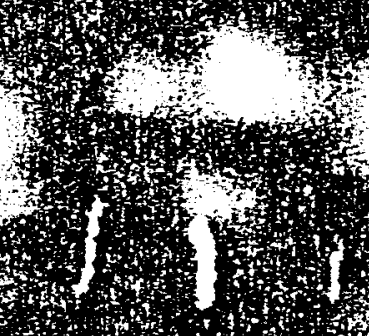

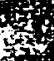

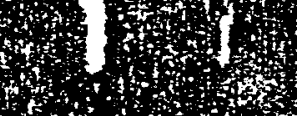

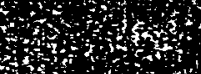




\section{An Interpretation of the Role of the Hoopoe in Afghan Folklore and Magic}

by NANCY HATCH DUPREE

THe hoopoe (Upupa epops, L.), a colcrful bird about in inches long, with slender black beak, wings striped with broad bands of black and white, russet breast and fan-like crest, is found throughout Asia, Africa, and Europe where its regal air and flamboyant plumage has assured it a prominent place in folklore.

Hoopoe-lore through time and space reveals an amazingly wide range of roles and attributes. ${ }^{1}$ It was regarded as a sacred bird in ancient Egypt where, according to Aelian, 'even upon the scepters of the gods a Hoopoe is an augmentation of honore'. ${ }^{2}$ The ancient Arabs ascribed many miraculous medicinal qualities to it while Persian poetic imagery credits the bird with such gentle qualities as filial devotion and virtuousness. Contrast til to the Scandimavian belicf that the hoopoe is a harbinger of war and that elsewhere in Europe the hoopue is cast in the role of a thicf. The Germans, among other Europeans, assign to it scatalogical names and roles and regard it as a... obscene and phallic bird. On the other hand, precisely because of these same stercoraceus inclinations, the ancient Romans seem to have elevated the bird to the position of Patron Saint of Manuring. On a world-wide basis, then, the hoopoe is an ambivalent character, at times good, at times consumately evil.

This paper explores legends currently told in Afghanistan and examines how they define the hoopoe's personality and, how society uses them to re-enforce certain cultural ideals.

Research shows that traditional folktales are fast being forgotten in Afghanistan and too often the young, especially the coming urban generation, have never heard about the hoopoe. It is well, therefore, to record them before they disappear. On the other hand, not one of these stories was collected from a professional storyteller. They were told in cities, villages and nomadic camps, 
by literates and non-literates, religious leaders, farmers, herders, scholars, soldiers, cabinet ministers, diplomats, and distinguished members of the royal elite. Stories came from both men and women, old and young, though significantly, the majority were 40 years or over. For many, these hoopoe legends are now just fond memories from the past, but for many others, they still remain functionally alive within the cultural fabric.

Afghanistan's extremely complex ethnographic picture is fairly represented with stories from several groups of Pushtun, as well is Tajik, Baluch, Herati, Uzbak and Turkoman. No stories were identified from isolated Nuristan on the eastern border because tales about birds do not figure prominently in Nuristani folklore, at least in the Kalashum ${ }^{3}$ and Kamdesh areas, although the Kafirs, converted to Islam as late as $1895^{-6}$ and since known as the Nuristani,worshiped an extensive pantheon of nature spirits.

The languages spoken by various Afghan ethnic groups are equally diverse, representing both Indo-European (Pashto, Tajiki, Baluchi, Dari, Kafiri) and Uralic-Altaic (Uzbaki and Turkmani). It is not surprising, therefore, that the hoopoe is known by many different names. Many of these are onomatopeic, a characteristic they share with names used in other nations: epops (Greek); upupa (Latin); huppe (French); udod (Russian); hudhud (Arabic, Hindi, also widely used in Afghanistan); poppoo (Pashto of Ghazni area); popak, bobak (Iranian Persian); bubuti (Pashto of Logar Valley); babotinkai (Pashto of Paktya area); popishak (Afghan

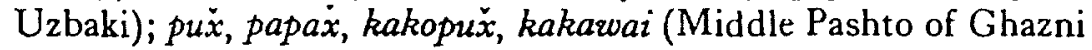
area); ututak (Dari or Afghan Persian; Pashto of Laghman and Logar); utundurok (Kafiri of Kalashum, Waigal Valley); kadak (Kafiri of Bagramatal ${ }^{4}$ ); dudek (Polish); dukhiphath (Hebrew).

These names reproduce both calls given by the hoopoe, the hup-hup, hup-hup when at ease and the much harsher warning call it uses as it approaches the nest, or is startled. Pu $\dot{x}$ almost exactly reproduces this difficult sound, the $\bar{x}$ starting at the back of the throat and literally hanging there to produce a sound half-way between the hard $k h$ used by northern Pashto speakers (the Pakhtun) and the soft sh used in the south by the Pushtun. It is a sound unique to Middle Pashto spoken in the Katawaz-Ghazni area. ${ }^{\circ}$

The onomotopoeic names are sometimes descriptive. Bobak is a 
term used for an unmarried teenage girl, i.e., something lovely; ${ }^{\circ}$ popak are pompcns used to decorate bridal pilli,ws. Both eavelope the hoopoe with an aura of romantic happiness.

Only one story explains an onomotopoeic name.

Once there were two brothers who were very fond of mulberries. One day the younger brother flew into the hills and never returned. Every year now, when the mulberries ripen, the elder brother flies from mulberry grove to mulberry grove calling ' $u$-tut, $u$-tut' ( $t u t=$ mulberry; 'Oh! Look! Here are mulberries!') in the hopes that his brother will hear him and find his way home.?

This melancholy little tale is unique to Afghan hoopoe-lore, characterized by an almost irresistible cheerfulness in marked contrast to many European traditions representing the hoopoe as a hapless soul cursed and entrapped for some past misbehavior. ${ }^{8}$

In addition to onomatopoeic names, different ethnic groups assign descriptive local names. Dari speakers frequently use shauna sarak (shauna = comb; sar=head; $a k=$ diminutive), Little Crested One, interchangeably with the onomatopocic ututak. Many Uzbak (Turkic speakers of the north) use this name and the Tajik (Dari speakers) sometimes use the variant taj sarak (taj= crown), or Crowned. The Turkoman of Andkhoi refer to the hoopoe as tarak kush (tarak=comb; kush=bird), The Crested Bird. Some Pashto speakers (Bajaur) use $t$ sar, ${ }^{10}$ Crested.

Most Pashto speakers use the term mullah chergak (mullah = Muslim religious leader; cherg =cock; $a k=$ diminutive), loosely translated as Bantam Mullah. Several interpretations for this amusing nomenclature are current in the conservative southern Pushtun city of Kandahar. Though zealously upholding the principles of Islam, the Kandahari often view their religious leaders with less than total reverence and jokingly refer to three. behavioral similarities between a hoopoe and a mullah. None are particularly complimentary: first, both strut about, constantly mindful of their own importance; second, the hoopoe stays away from the female during the day, going to her only under cover of darkness, or, his public face fails to match his private face; finally, both mullah and hoopoe prefer to stay sheltered near old walls, fearing to venture out into the open and therefore are cowardly. ${ }^{11}$ Indeed, the hoopoe does move with a brisk self-assured manner 
even though known to be a timid bird, preferring to live and nest in crumbling mud walls on the outskirts of villages. That it breeds only at night has not been substantiated.

In Herat, among other places, the hoopoe is likened to a mullah because its natural habit of bobbing its head up and down as it moves across the fields suggests the novernents of the Muslim prayer. Elsewhere, as in the Kunar in Eastern Afghanistan, the hoopoe is said to be called mullah chergak because its crest resemblos the large, showy turbans sometimes worn by important mullahs. ${ }^{12}$

Many Uzbak use the term shauna sarak, but some call the bird alopopishak (alo=piebald; popishak $=$ hoopoe ${ }^{13}$ ), as do many Tajik living among the Uzbak in the north. ${ }^{14}$ In some areas around Mazar-i-Sharif, a major northern city, saspopishak (sas=smelly) is used by certain Uzbak groups ${ }^{15}$ for reasons discussed below.

The Baluch in the Hilmand Valley in the south-west call the hoopoe Suleimanai murg, ${ }^{16}$ the Bird of Solomon.

The consistent use of the diminutive $a k$, a complimentary form of address for a child, brother, sister, or a pretty little thing such as a kitten or a bird, strengthens the pleasing portrait already established by the bird's colorful plumage. Considering colorful birds as the embodiment of happiness is common to many folklore traditions and color is especially treasured in Afghanistan where a great deal of the terrain alternates between barren rocky cliffs and dusty deserts. The eye-catching flash of a hoopoe across this landscape naturally projects an image of happy well-being.

Not all Afghans view the hoopoe as a symbol of pleasure. Many regard it as a smelly bird; mothers admonish their young to stay away from its nest; malodorous persons are jokingly called hoopoes; some refer to the hoopoe as a Hindu, an extension of occasional discriminatory attitudes toward other peoples and religions. ${ }^{17}$ The aversion expressed in these attitudes relates to the unpleasant protective odor the hoopoe acquires while it sits with its young. Others abhor the hoopoe for its dirty eating habits for, in addition to neatly clipped urban lawns, it shows a marked preferince for worms pecked from dungheaps. Every nation with a body of hoopoe-lore includes some reference to these natural habits, the earliest appearing in Leviticus $11: 19$ and Dcuteronomy 14: $18^{18}$ where the hoopoe is listed with other birds considered 
unfit for eating. According to Muslim tradition, the Prophet Mohammad forbade it to be killed but controvetsy exists over whether hoopoe flesh is forbidden or permitted. In Afghanistan it is forhidden in the south around Kandahar and in the Gurziwan Valley (Faryab) and Aq Kupruk (Balkh), in the north.

European stories emphasizing the hoopoe's stercoraceus traits elaborate on its eating habits and its admittedly untidy nest, and embellish these unsavory aspects to defame the bird's character and its reputation. ${ }^{20}$ 'The Afghan view is generally more compassionate. In the hill villages of Paghman above the capital city of Kabul, an area much frequented by the hoopoe, the villagers explain it thus: Because the hoopoe is so beautiful, everyone would like to catch it and so, to protect it, God gave it a bad smell. ${ }^{21}$

Overriding any pejorative connotations is the role of the hoopoe in bringing together two fabled lovers which clearly establishes it as a harbinger of romance, happiness and good-fortune. On mention of a hoopoe many will quote Hafiz immediately:

Oh! Hoopoe flying on the dawn-wind, to Saba I am sending you; Look, how far it is; from here to there, I'm sending you!

It's a pity - a bird like you in this dustbin of care:

to find the nest of fidelity I am sending you. ${ }^{22}$

These verses from the pen of one of Persia's most celebrated poets refer directly to Sura XXVII : $17-45$ of the Koran ${ }^{23}$ in which the hoopoe introduces King Solomon to the Queen of Sheba, the beauteous Bilquis. Whereas the story of the hoopoe is thus the special concern of the Koran, this collection demonstrates that the Koran by no means exhausts all aspects of the hoopoe legend. In Afghan villages where 95 per cent of the population is nonliterate the Koran, an occasional religious commentary, or a Persian or Pashto translation of the popular ninth century A.D. Arabic Qasas al-Anbia (Tales of the Prophets) by Al-Th'alabi often represent the only reading material in a village. In the case of the hoopoe legend, the Qasas al-Anbia elaborates on the Koranic account, and many Afghan tales follow these elaborations closely. However, they also contain additional flourishes which embue the familiar characters with specific Afghan ideals.

Contemporary Afghan oral tradition emphasizes one significant departire from the Koranic version. Ir the Koran (v. 23-37) Ki.ag 
Solomon hears of the sun-worshipping Bilquis from the hoopoe and immediately dispatches the bird with a message calling upon the queen to surrender unto the teachings of the True God. Consider the following popular Afghan version of the encounter.

King Solomon was king of all the world; every human being, every animal, every bird, every fairy, and every genii bowed before him.

Solomon's capital was in Iraq where, one day, a man brought the king a picture of the Queen of Saba who ruled near Jordan. The beauty of the face he saw before him was so radiant he could not gaze on it for long. In that very instant he fell in love, not with one heart, but with one hundred hearts. ${ }^{24}$

From that moment the king was consumed with thoughts of a meeting with the beauteous queen. He searched throughout his kingdom for the fastest thing alive and found it was the hudhud. King Solomon sent him to Saba with a message imploring the queen to visit him as soon as possible.

The hudhud flew to Saba and when he delivered the message to the queen he extolled the virtues of King Solornon with such eloquence that she started out without making the slightest preparations for the journey.

Reaching King Solomon's palace she found, or so she though.t, his throne seated in a pool of water. Not wishing to get the hem of lier dress wet, she lifted her skirt above her ankles and thus approached only to discover that the foor was in reality made of purest crystal. This filled her with wonder and when she came before the king and looked into his eyes she fell in love, not with one heart, but with one hundred hearts.

King Solomon and Queen Bilquis were married; and they lived happily ever after. ${ }^{25}$

Afghan fondness for love stories thus converts an account of a king conquering in the name of God into a purely romantic tale. It differs importantly from the majority of Afghan love stories, however, in that it brings king and queen together to live happily ever after, while most Afghan love stories seem to end in abject tragedy for one or both of the principals.

Wealth is also associated with the hoopoe because of its close relationship with royalty. Its crown-like crest above feathers shining like rich silks heightens the image. This facet is expressed in the belief that a house selected by nesting hoopoes must prosper, for surely the hoopoe will only consort with those possessing the same virtues as that king and queen for whom it carried messages. ${ }^{28}$ 
The hoopoe's role as messenger is extremely important. In several Islamic countries the bird is popularly referred to by such terms as quced ul-Sulaiman, Arabic, Solonon's Messenger; morgh-e-namebar, Iranian Persian, Letter-Bearing Bird; favas $k u s ̧ u$, Turkish, Courier Bird. ${ }^{27}$ Afghan names do not refer to the hoopoe specifically as a messenger but the role figures prominently. On seeing a hoopoe, for instance, Afghans may remark that someone present is bound to receive a happy message. The hoopoe is always portrayed as Solomon's messenger even when, as in this Uzbak story, it lives with Queen Bilquis.

One day King Solomon sat on his throne and he was very, very unhappy. 'I am king of all the birds, and animals and insects and reptiles of the world. They all live in my domain; pay homage to me. Only one bird amongst all these pays me no heed: the alopopishak does not even choose to live in my kingdom. I wonder what keeps this beautiful bird away?'

The more he brooded over the matter, the more despondent he became until finally he sent for the bird, asking him to come immediately.

When the alopopishak arrived, King Solomon put this question to him: "Why do you not live in my country, along with all the other birds? What keeps you away?'

'Oh! Great Solomon!,' he said. 'Wou are irdeed a great king with a wonderous throne and a rich kingdom but all you have is naught beside the beauty and the virtue of the one I serve.'

Irked, King Solomon demanded, 'And who might that be?'

"The most glorious Queen Bilquis, loveliest of all women, most sagacious of all rulers.' So eloquently did the alopopishak describe the queen that the king fell in love with her, sight unseen. Composing a love letter, he entrusted it to the alopopishak who delivered it to the queen to whom he related the virtues of King Solomon. Again, he spoke so well that the queen consented to marriage and they lived in happiness forever. ${ }^{28}$

As might be expected, the manner in which the message is delivered undergoes considerable elaboration in these popular Afghan versions. The nomadic Baret (Pushtun) living among the Baluch in the south-west describe the incident with these innovations:

King Solomon wanted to send a letter to Queen Bilquis because he had heard she was very beautiful. Searching for a suitable messenger, he gave the letter to a cock because cocks are allowed to wander in and out 
of houses at will. The cock tucked the letter under his wing and started oft dutifully, but whet he arrived at the queen's palace his attentior. was diverted by some delicious morsels on her doorstep.

Back in Solomon's palace, the king waited and waited for a reply, wondering why the cock did not return. Concerned, he asked the Sulaimanai murg to go in search of the missing cock and find out what was happening.

The Sulaimanai murg found the cock happily pecking away at his food and for an excuse he told the Sulaimanai murg that the queen was sleeping behind locked doors and therefore he was waiting until such time that she might arise and open the door.

The Sulaimanai murg, however, took the letter away from the cock and flew through the window, straight into the queen's bedroom, where he laid the letter on her bosom.

As he left her side, he gently fanned her face with his wings and then he perched himself upon the window sill in order to watch her awake. The queen was most astonished to find the letter when she awoke, for she knew her room was tightly locked. About to sound the alarm, she suddenly saw the Sulaimanai murg on her window sill whereupon she smiled and was afraid no more. ${ }^{20}$

No simple messenger, the hoopoe also performs as an eloquent go-between, an institution crucial in Afghan society, although urban girls now have more say in the choice of mates. For many, a successful'match still depends on the go-between, who must bargain well, describe with a flair, parry argument and seize each psychological advantage. The naturally jaunty hoopoe moves across field and hillside with a self-assurance which admirably qualifies it for this complex role.

This raises the interesting question of whether the hoopoe should be considered as a male or a female. Dari and Uzbaki have no gender but the majority of Dari and Uzbaki speakers arbitrarily select the feminine when translating into English. The importance of the hoopoe's role as a go-between accounts in part for this unconscious selection of the feminine for although men participate in various stages of the marriage arrangements, women are the conspicuous organizers of all pre-nuptial rituals and go-betweens are traditionally women. Furthermore, the hoopoe's unannounced entrance into the queen's chambers, and its brash approach right up to her couch is clearly in very poor form according to Afghan moral codes if the bird is characterized as a male. 
TH:. HOOPOE IN AFGHAN FOLKLORE AND MAGIC

However, Pashto does have gender and, interestingly most Pashto speakers regard the hoopoe as a male. The masculine is of course implicit in the name mullah chergak. 'Tle poppoo of Ghazni is also masculine. In Laghman Province in tive east, and in Logar Province, south-east of Kabul, Pashto speakers use the term ututak. However, in Laghman the feminine gender is used, in Logar, the masculine. ${ }^{30}$ The Baluch in the Hilmand Valley (speak-. ing Baluchi) consider the Sulaimanai murg to be male. ${ }^{11}$ Gender seems not, therefore, to be crucial to the hoopoe image in Afghanistan partly because of the multifarious qualities attributed to it and partly because these admirable qualities are deemed equally applicable to man and woman. How different from Rumania where the consistent portrayal of the hoopoe as a female is essential to its 'feminine' image as a greedy, deceitful, conniving, nagging wife! $!^{32}$

That the hoopoe symbolizes romantic bliss in Afghanistan is further substantiated by its magical reputation by which it becomes a sacrificial victim of love precisely because of its success in bringing together Solomon and Bilquis to live happily ever after. Using a quill from its wing, sorcerers (kodgar in Pashto, both men and women) write potent amulets (ta'awiz) in hoopoe blood obtained from four essential incisions known only to them. ${ }^{39}$ These amulets assure success in romantic conquests and protect a loved one from the covetous eyes of a rival. They have even been known to turn a disenchanted husband into a passionate lover. ${ }^{\text {sa }}$

Another potent charm may be obtained by burying a hoopoe for forty days and then carefully collecting all the bones. To ascertain which of these has magical properties, however, it is necessary to take them to a flock of sheep and rub each bone, one by one, against a particular sheep, stepping away after each is tested. When the sheep follows, the magic bone has been found and may be used to stroke a loved one who is then bound to follow. Furthermore, should passion cool, the same bone may be used and the loyed one will disappear quietly. ${ }^{35}$

The hoopoe's head is kept by some Uzbak women, especially in areas where men take two or more wives. Should one wife fight constantly with the other, friends will admonish them by saying, 'Gol find the head of a hoopoel' in the belief that this talisman will ènsure a happier household. ${ }^{36}$ By extension, some men and women 
wear hoopoe amulets in order to be popular, ${ }^{37}$ Certain magical formulas must always be chanted by a kodgar (often a mullah as well) and blown over the amulets before they become effective, however.

In some areas of the north, hoopoes are sometimes looked upon as being Hindu, not because of the religious prejudice mentioned above, but because the women of India are renowned for their finesse in love. Those who look upon the bird as a Hindu keep hoopoe amulets in the hopes of acquiring some of the reputed artfulness. ${ }^{38}$

Many pre-Islamic practices were probably brought to the Afghan area by the Arabs who considered hoopoe blood and various organs as indispensable ingredients for magical charms. ${ }^{39}$ Very possibly these factors influenced the Prophet Mohanmad when he ruled against killing the hoopoe. Magic and the practice of witchcraft are inconsistent with literate Islam, but inany pre-Islamic practices survive in the villages and among urban non-literates.

In another series of stories the hoopoe emerges as something more than a romantic portent of good-fortune and becomes Solomon's super-conscience.

King Solomon was leading his armies through the deserts of Arabia where the heat was so intense that the king thought he would faint. He called for the hudhud to find water for them, but the naughty bird was nowhere to be found. The king sat in the desert getting hotter, and thirstier, and more and more furious. Still the hudhud did not appear. Losing patience, the king sent an eagle to fetch the wayward bird and warn him that unless he returned with a very good excuse, his end was most certainly at hand.

When the eagle returned with the hudhud, King Solomon caught hold of the bird by its neck and was about to dispatch him inmediately when the hudhud managed to gasp:

'Oh! Prophet of Godl Rememberl and be afraid of Judgment Day when you will account to God for all you have donel'

Reminded that punishment may not be inflicted without just cause, the king loosened his hold, whereupon the hudhud told this story of his journey to the Kingdom of Saba. ${ }^{\mathbf{} 0}$

This story also features the widely held belief, prevalent in ancient Egypt $^{41}$ and prominent in the Arabic Qasas al-Anbia, that the hoopoe possesses miraculous powers for detecring under- 
ground water. 'Throughout Afghanistan many groups point to the hoopoe's distinctive mannerism of bobbing its head up and down as an indication of its constant search for hidden springs.

Several variations of this story occur. The Uzbak say that one day King Solomon was flying through his kinglom on his throne. He passed over the deserts of Andkhoi, and near Balkh it became so uncomfortably hot that he asked all the birds in the world to fly above him as a canopy. When they assembled, however, one small ray still penetrated, the king ordered a roll call, and the hoopoe was found missing." Incidentally, the hoopoe was so enamored of Afghanistan on this, its first visit to the area, that it decided to make its home here. ${ }^{43}$

In all versions, however, once the hoopoe's absence is detected, the king explodes with anger. His threat of grave punishment is related in the Koran (v, 20-1) and highly elaborated in the Qasas al-Anbia where Solomon threatens to pluck out its feathers and throw it to the ants, deprive it forever of a mate, jail it for life, or kill it.

The manner in which the hoopoe reacts to the angry summons adds three new attributes to its character: independence, courage and wisdom. By daring to leave Solomon's entourage and thus knowingly court the royal wrath, it establishes its independent nature. 'Then, after being caught, it proves its courage by calling the great Solomon to task for unjust behavior. Even those Afghans who remember little about the hoopoe do recall that the hoopoe got into some sort of trouble with Solomon and somehow talked its way out with wise and witty remarks. Here the hoopoe personifies probably the most ideal personality type in Afghanistan, the charismatic warrior-poet who fights for just and moral causes with well-turned phrases at the tribal council, as well as with bravery in combat.

The hoopoe's glorious crest is generally considered to represent a crown which it received as baksheesh from King Solomon for its wise sayings. ${ }^{14}$ This oral tradition is beautifully expressed by the twelfth-century Persian poet Farid ud-Din Attar in hisallegorical Mantiqut-Tahir (Conference of the Birds) in thick the blyds of the world set out to find a king with the hoopovas their gufda. It Jeads them to a Knowledge of Self which, borh Eof unity with God, makes every man a king unto himself. ${ }^{\text {s }}$

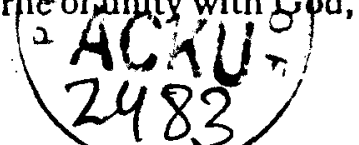


Another explanation for the origin of the hoopoe's crest, however, relates to the flight over Balkh. According to this tale, a whole flock of hoopoes came to the king's rescue without being asked. Grateful, Solomon asked them to name their reward and they asked for a golden crown for each. At first jubilant, their joy soon turned to terror as hunters eagerly shot them down for the treasure on their heads. Seeing their distress, King Solomon turned their golden crowns into crowns of feathers which hoopoes wear with pride, opening and closing them in order to show them off. ${ }^{46}$

Nowhere in the Afghan area is there any suggestion of the European beliefs that the hoopoe stole its crest from the turtle or borrowed it from the cuckoo never to return it. ${ }^{47}$ The Afghan hoopoe is never guilty of any such moral lapses but a saucy craftiness is, however, very much a part of its character.

One day a hungry fox walked down the road pretending he was on his way to the hajj. There he met a rooster who asked, 'Where are you going?'

'I'm going on the hajj, the fox replied.

'Better to be two than one, I'll come with you,' said the rooster. And the two continued walking down the road.

Som: parsangs later they saw a partridge who asked, 'Where are you going?' When told they were on their way to Mecca the partri sge said, 'Better to be three than two, I'll join youl' And the fox, the rooster and the partridge walked on, telling stories.

Soon they came upon an alopopishak sitting on a big rock by the side of the road and he too joined them for he said, 'Better to be four than three when going on a long and dangerous journey.' And the four went on walking.

As the day came to a close, a high mountain loomed up before them and the fox said, 'It is getting late. Some of my relatives live in a cave in this mountain. Let's spend the night with them.'

So they all climbed up to the cave but when they arrived they found it empty. 'My relatives have obviously left for the hajj,' said the fox. 'Never mind. We can still sleep here safely.'

All night the fox lay without sleep, getting hungrier and hungrier. Then, just before dawn, the partridge woke up, hopped upon a rock and started to sing. Seeing his chance, the fox rose up and said, 'Was your father a musician that you presume to sing so?' Before the astonished partridge could answer, the fox jumped on him and gobbled him up. 
At dawn the rooster stood up, flapped his wings anchstarted to crow. Another good morsel, thought the fox who came forward and said,

'Hey, you! Was your father an inam in a mosque that you stand there pretending to give the call to prayer? Go to the mosque and crow, not here!' And before he knew what was happening the rooster also disappeared down the throat of the fox.

Only the alopopishak remained. The fox could hardly wait. Finally, the alupopishak flew to a perch to greet the day calling $u t-u t, u t-u t$ and the fox came forward as he had before and said,

'You! Was your father a king, and your grandfather a king before him that you place such a splendid crown upon your head?' Having seen the fate of his companions, the alopopishak quickly flew to another perch and bobbed his head up and down like this, saying 'Yes, yesl'

The fox pounced. The alopopishak flew a pace and again bubbed his head like this saying, 'Yes, Yesl' Again and again the one pounced and the other flew and they moved further and further across the valley.

Finally they came near a qala (walled residence) where the alopopishak sat upon the wall calling and calling, ut-ut-,ut-ut. Two dogs in the gala came out to see what all the fuss was about and there they saw the fox. The chase was on. Around and around the gala they ran while the alopopishak cheered them on until the dogs caught up with the fox and tore him into small pieces.

'Yes,' said the alopopishak, 'I am a king. Otherwise how could I command such a fine bodyguard to protect me and tear you to pieces. Of course $I$ am a king!' 4

The hoopoe's reputation for wisdom predominates, however, for the hoopoe is closely associated with the wisdom of Solomon, a tradition which is no doubt of pre-Islamic origin just as Solomon's acquaintance with the speech of birds and animals is based on 1 Kings (iv: 33). According to this tradition in Afghanistan, King Solomon once gathered together all the beings of heaven and earth in order to determine which was the wisest one of all. 'This multitude chose the hoopoe by unanimous decision. ${ }^{49}$

Many of these stories stress the fact that Solomon is the king 'of all the world', human beings, animals, birds, insects, fairies, and jinns without exception, and yet it is the hoopoe, alone, to whom he listens. Folk-art portraying this show's King Solomon on his throne with the hoopoe perched to one side. The vast multitude faces center, expressions intent, and the hoopoe sits there with its crest open, its gorgeous plumage shining, obviously enjoying th: 
sit dation. Modesty is certainly not attributed to the Afghan hoopoe.

The hoopoc's most oft-repeated advice is given to Solomon after he marries Queen Bilquis.

After Solomon married Bilquis, he was so infatuated he would do anything she asked. One day she asked for a new mattress and pillows, specifying that these must be stuffed with the feathers of each and every bird in the world; absolutely no bird was to be left out.

Solomon called for all the birds and stripped them of all their feathers but when Bilquis was presented with the mattress she declared that the feathers of one bird were missing. Ordering a count, it was found that the shauna sarak had not contributed his feathers.

Angry, Solomon sent a camel to fetch the shauna sarak. The camel returned saying the bird refused to come. The king sent a horse, but still he refused. A dog was sent and the shauna sarak returned with it.

'Why would you not come with the camel,' the king demanded.

'Ohl it was so big and I am but a small and timid bird. I was afraid!'

'Why not with the horse?'

'How could $I$, a mean and humble thing, come with such a handsome animal!'

'But you came with the dog. Why is that?'

'Because I am as lowly and as despised.'

Loosing patience with such flippant answers, the king said, angrily: 'Enough of your banter. Why didn't you come in the first place? Why inconvenience me by making me send for you?'

'I was busy.'

'Doing what?'

'Counting the number of men and women in the world to see which are more.'

'And what did you find?'

'There are more women than men.'

'Ridiculous! Everyone knows more boys are born each day than girls.'

'Ohl but $I$ have included some men among the women. Those men who follow the commands of women and thereby stray from the path of goodness do not deserve to be counted among men!'

Chagrined, King Solomon returned all the feathers to the naked birds. ${ }^{60}$

In other versions told in urban areas and by mullahs from both the city and the village, griffins, mythical birds and giants are sent forth to fetch the hoopoe, rather than the more familiar camel, 
horse and dog, the highest and lowest in prestige among the animals. All versions, however, use a scrics of contrasting messengers ranging from the fearsome to the timid. In a parallel version from the North, a hunting hawk returns unsucessfully white an owl succeeds for, says the hoopoe, "The owl is as timid as I.'s1 In blatantly feigning fear and sarcastically identifying itsclf with the humble and the timid, the hoopoe emphasizes its cocky, independent character and sharpens its final message.

The hoopoe's final devastating comment on Solomon's poor judgment is sometimes prefaced with other examples of irrefutable moral logic. Once when the hoopoe returned, the king purposely refrained from asking where it had been and began by asking sarcastically,

"Tell me, since you are so very wise, are there in this world more persons dead and buried, or more alive and moving about?'

'Ah,' said the hoopoe, 'it is very clear. There are more dead and buried, for those who do not pray and do not fast are, of course, in reality dead.'

'Alright,' said King Solomon, 'then tell me, are there more men or more women in this world?'

'More women, of course, for some men become women when they give in to silly womanly demands!'b2

Bilquis' unreasonable demands change from storyteller to storyteller. Sometimes it is a throne made of bird bones she wants, or a flying carpet made of bird feathers. ${ }^{63}$ Once she even demanded a castle of butter, according to this story from the Pashto-speaking South.

King Solomon ordered all the milk-giving animals in the world to assemble near his palace where they were called upon to produce great quantities of milk so that King Solomon could build a castle of butter for Queen Bij yuis.

The animals gave milk all day long but the walls of butter erected during the night quickly melted under the sun during the day. Again and again, day after day, the poor anirnals gave more and mure milk. Soon they became exhausted and Solomon called together all the birds in the world and instructed them to fly over the castle to keep the sun from melting the walls. This proved quite successful except for one small ray that pierced the screen, reducing the Queen's favorite room into a soggy mass. Incensed, Solomon ordered a rull call, the mullah chergak was found missing (and the story continues). ${ }^{\text {bt }}$ 
In another version, also from the South, the hoopoe obeys the king's summons but soon grow's tired of flying around in what it considers a senseless exercise, so it leaves. ${ }^{55}$ Folklore often assigns dire consequences for such disrespectful disobedience. The Rumanians, for instance, say the hoopoe was condemned to forage in dungheaps because it once complained to the gods about its food. ${ }^{58}$ In Afghanistan, because its actions are governed by superior moral principles, it escapes punishment and emerges with its character not only intact, but its reputation enhanced.

This reputation also accounts for the absence of stories suggesting that the bird exists in a metamorphosed state although metamorphosis does occur in hoopoe tales from neighboring Islanic Iran and in Afghan bird tales concerning the crow, dove and sparrow ${ }^{57}$ and animal tales about the bat, ${ }^{58}$ porcupine and turtle. ${ }^{68}$ But in Afghanistan all these human beings in animal form were once guilty of sloth, theft, cruelty or pride, qualities which cannot be tolerated in association with the hoopoe because its image does not permit them.

One final example illustrates the richness of these variations on a single therne. Asked to gather all the birds to fly as a canopy over the queen's buttery castle, the hoopoe immediately runs into difficulties:

The Sulaimanai murg went to the cock and asked him to attend the king but the cock said: 'I' $m$ having too much fun with my hens. I'll come along later, but leave me alone for the time being.'

Seeing that this wass so, the Sulaimanai murg said, 'Alright, I'll go fetch the heron and then we'll all go to Solomon together.'

When the Sulaimanai murg came to the heron, however, he found him quietly enjoying his solitude by the river, catching fish. In answer to the summons, the heron said, 'I'm so happy here, I hate to leave. Wait a little until I've caught a few more fish, and then we can go together.'

While the Sulaimanai murg waited, he too began to relax in the peace of the countryside. Why, he wondered, should these birds be taken away from their happy pursuit of life? In the palace, however, King Solomon fretted away the time and finally, as a punishment, he sent the hawk after the Sulaimanai murg.

The Sulaimanai murg flew back to the palace where a very angry king demanded: 'What's been keeping you so long? The walls are melting while you sit and fritter your time away l' 
Right them, on the spur of the moment, the Sulamanai murg decided to make up a story and teach the king a lessun.

"The cock and the heron are having at terrible argument trying to decide whether there are too many men or too many women in this world," he retorted. "The cock says there are more women, the heron says more men. I was considering who was right about this important question."

'And what is your judgment?'

'I think the cock is right, for some men must be counted with women when they give in to womanly foolishness !'su

The hoopoe's injunction against deferring to feminine whims is present in much Islamic folklore; in Afghanistan it is the most popular theme associated with the hoopoe and may be heard, in many different forms, in every part of the country. The popularity of the theme may be partly explained by the fact that Afghan society is generally described as ideally patrilineal and patriarchal. Sura IV (entitled Women) of the Koran spells out an honorable and dignified place for women in society while still encouraging masculine superiority by maintaining that 'Men are the managers of the affairs of women ... for that God has preferred in bounty one of them over another,... Righteous women are therefore obedient ... The realities concerning the place of woman in the household, however, depart considerably from the accepted ideal in many cases and these hoopoe tales cautioning against homage to women are an attempt to re-enforce the ideal over the real. The universal popularity of the theme tacitly indicates that the men of Afghanistan are aware of the reality and recognize, either consciously or unconsciously, the influence of their womenfolk. Men tell the tale with obvious enjoyment, gleefully dwelling on the means by which the queen led the great Solomon astray thereby recognizing the human situation in which even the wise and mighty fall victim to feminine wiles. The storics clearly articulate the ideal, but in the telling, the reality appears just as clearly.

Most of these stories emphasize the hoopoe's irreverent manners. Afghans are inveterate jokers ${ }^{61}$ and they enjoy these exchanges which add to the hoopoe's cocky image as a quick-witted joker nimbly besting the king with short, pithy lessons on inoral behavior.

These simple statements, infinitely more appealing than pon- 
derous philosophical discourses to literate and non-literate alike, speak to the pretentious on a number of different codes. For example:

The Shauna sarak invited King Solomon and all his retinue to dine with him on an island. The king came and quietly settled himself by the sea. His courtiers, his soldiers and his servants, however, set to quarrelling as they jockeyed for position. Each tried to snatch a seat as close to the king as possible and thus gain prestige in the eyes of those forced to sit on the edge of the crowd.

The shauna sarak watched from a place high on a hill in the center of the island. When the clamor was over and all sat quietly envisioning a feast fit for a king, the shauna sarak flew from the hill with a grasshopper in his beak, and dropped it into the sea, saying:

'Oh! Mighty Assemblage, eat! If the meat is lacking, at least the sauce is plenty!'

The king was stunned. Soon, though, he began to laugh and laugh, while his followers sat glum and uncomprehending. Then the shauna sarak explained:

'Those caught in the web of self-pride and conceit may never know fulfillinent. ${ }^{\prime 22}$

A variant of the same tale was collected in a nomadic camp and contains some interesting cultural allusions for comparison.

One day King Solomon came to visit the mullah chergak and he brought his whole army with hin, a very large gathering because this king was king of all the world; the men, the animals, the birds and even the jinns.

The mullah chergak flew over to welcome the king. He spoke profusely about how honored he was by their visit to his humble home and then, seeing the king comfortably settled, he excused himself. He flew here and there and everywhere looking for food to feed this huge multitude. It seemed hopeless. Finally he caught a grasshopper which he hit and hit with his beak ${ }^{83}$ and after this he swished the pieces around in the river for awhile.

Finished, he flew back to the king and invited all to dine saying:

'Oh! King! eat of this most humble repast. There is plenty of soup and $I$ beg of you to excuse the absence of much meat. The late guest eats from his own forehead! ${ }^{\text {os }}$

The rules of hospitality are strictly adhered to by all levels of society in Afghanistan. Guests are always welcomed and always 
fed, even if it means watering the soup and dividing the soup meat into miniscule portions. The right to huspitality cntails cortain obligations, however, as expressed in the popular saying: The late guest eats from his own forchead, i.c., fortune lies in thoughtuluess and a late or unannounced guest takes his chances whether he be well or meanly fed.

These tales teach more than correct social behavior. The above tale was told in a nomadic camp tense with anxicty over the effects of a seemingly endless drought. One Khan had watched his flock of 140 ewes dwindle to 15 . To lighten the burde $\mathrm{n}$ of the disheartened, someone reminded the group that man must trust in the Almighty. To make his point he told the story of how King Solomon once presumed to feed all the animals in the world. On the day of the feast, however, one single fish appeared first and gobbled down every last morsel. King Solomon was thus reminded that: Allah has created the mouth and only Allah knows best how to fill it.

This story reminded another of the above story about $\mathrm{K}$ ing Solomon and the mullah chergak in which not even the great King Solomon could presume to be lucky at all times. The moral, re-enforcing the belief that it is appropriate to trust in the order willed by God, flows naturally from these stories and makes them psychologically very satisfying.

This enumeration of hoopoe roles and attributes in Afghanistan, therefore, reveals a multifaceted image. A symbol for romance, happiness, wealth and good-fortune, the hoopoe also stands as a champion-of justice and defender of such social and moral values as hospitality and righteous behavior. By its actions it defines and perpetuates such idealized character traits as independence, bravery, wit and wisdom. Above all, the hoopoe emerges as an individualist, probably its most uniquely 'Afghan' trait.

\section{NOTES}

1. Aristophanes, The Birds; C. Daniels (ed.), Encyclopedia of Superstitions, Folklore and the Occult Sciences of the World, vol, 2 (Chicago, 1911), p. 643; Funk and Wagnal's Standard Dictionary of Folklore, Mythology and Legend, vol. I (New York, 1949), pp. 502-3; W. H. Halliday, Indo-European Folk-Tales and Greek Leg'ends (Cambridge, 1933), pp. 91-100; W. Houghton, Gleanings from the Natural History of the Ancients (London, 1879). p. 207; G. Jobes (ed.), Dictionary of Mythology' Folklure and Symbols, part I (New York, 1961), p. 785; J. G. Kunstmann, The Hoopoe: A Study in European Folklore, Chicago University (private ed., 1938); H. Mussé, Persian Beliefs and Cusloms (New Haven, 
1954), p. 184; E. W. Martin, The Birds of the Latin Poets (Standford, 1914). p. 95 ; D'Arcy W. Thompson, A Glossary of Greek Birds (Oxford, 1845), pp. $54-7$.

2. Aclian, De natura animalium, x. 18; W. R. Dawson, "The Lore of the Hoopoe', Ibis, vol. I, 1925 (12th ser.), pp. $3 i^{-9}$.

3. Mohammad Alam Nuristani, Nishai, Kunar Province.

4. Bagramatal (Village on the Rock) is variously transliterated.

5. I am nuch indebred to Mr Abdus Sattar Shalizi for this information.

6. Maulana Khasta, Kabul; Mohammad Asif, Kabul.

7. Paghman (Kabul), Pushtun, f., 35 yrs., urban literate. Source includes: cown/village ('Province), ethnic group, sex, age, social group. No specifics if story or belief generally representative.

8. M. Gaster, Rumanian Bird and Beast Stories (London, 1915), pp. 16o, 162,167 ; Grimn's 'The Bittern and the Hoopoe'; Sophocles'-Terus.

9. Abdul Karim, Andkhoi (Faryab).

ro. Abdul Rasool Amin, Kunar.

1. Abdul Kazik Palwal, Kandahar.

12. Abdul Kasool Amin, Kunar.

13. Dom Quala Aliabad, Gurziwan (Faryab).

14. Aq Kupruk (Balkh).

15. Mazar-i-Sharif; groups from Mazar now living in Kabul.

16. Abdul Razik 'alwal, Kandahar.

17. Mainly an urban attitude from Kabul and vicinity (Pagliman and Logar) among Pushtun, m./f., 30-50 yrs, literates. Kabul has a sizeable Hindu community.

18. Mistakenly translated lapwing in earlier versions; corrected in some modern translations.

19. See Encyclopedia of Islam: hudhud.

20. Kunstmann's thesis categorizes these attitudes.

2I. Paghman (Kabul), Pushtun, f., 35 yrs, urban literate.

22. Primarily Kabul, mixed ethnic groups, n./f., 50-6o yrs, urban literates. Trans.: P. Avery and J. Heath-Srubbs, Hafiz of Shiraz (London, 1952), p. 36.

23. A. Arberry, The Koran Interpreted (London, 1964), pp. 383-6.

24. A popular Afghan saying.

25. Kabul, Pushtun, m., 55 yrs, urban literate.

26. Dom Qala Aliabad, Gurziwan (Faryab), Uzbak, m., 12 yrs, farmer/ schoolboy; Kabul, Pushtun, m., 60 yrs, urban literate.

27. The magnificently plumed hats worn by seventeenth-century Turkish Janissary officers carrying messages were probably designed with the hoopoe's crest and its traditional messenger's role in mind. That the bird was named after the courier seems less likely; see C. Swainson, The Folk Lore and Provincial Names of British Birds (London, 1886), p. 107. H.E. the Turkish Ambassador to Afghanistan, Mr Hamit Batu, kindly provided illustrations.

28. Dom Qala Aliabad, Gurziwan (Faryab), Uzbak, m., 45 yrs, mullah/ farmer; Mohammad Ibrahim Khan, trans.

29. Landey (Hilmand), Baret Pushtun, im. 35 yrs, farmer, non-literate. Collected by A. R. Palwal.

30. Dr Abdul Kayeum, Professor Mir Ansari, Dr Mohammad Rasoul Taraki, and Professor Habibullah Tegey kindly discussed these complexities.

31. A. R. Palwal.

32. Gaster, op. cit., pp. $162,164,229$.

33. Badwan (Kandahar), Pushtun, m., 30 yrs, mullah/farmer, non-literate.

34. Said Qala (Kandahar), Pushtun, m., 40 yrs, farmer, non-literate.

35. Badwan (Kandahar), Pushtun, m., 30 yrs, mullah/farmer, non-literate.

36. Aq Kupruk (Balkh), Uzbak, f., 30 yrs, farner's wife, non-literate;

Tajik, f., 6o yrs, landowner's wife, non-literate.

37. Aq Kupruk (Balkh), Uzbak, m., 27 yrs, farmer, non-literate.

38. Aq Kupruk (Balkh), Uzbak, f., 30 yrs, farmer's wife, non-literate. 
39. See Kunstmann, op. cit., Chapter Il for an extensive discussion of the hoopoe's magical reputation in the Middle East and Europe. Dawson, op. cil., pp. 34-6 also records many wondrous prescriptions.

40. Kabul, nixed ethmic groups, f., teenagers/50-60 yrs, secondary schoolgirls who collected stories from their granduothers and wrote them up as a clasa project organized by Mrs Nabi Kohzad. 'Trans. by Husain Kazi.

41. James Orr (ed.), The International Standard Bible Encyclupedia, vol. III, p. 149, Michigan 1955; Thompson, op. cit., p. 57.

42. Tawberyan (Herat), Herati, m., 60 yrs, mullah, litcrate, as told by Hatizullah Baghban; a popular version also related in the Qusas al-Anbia, Qader Fahim and Toralay Shafaq trans.

43. Sarchacon (Faryab), Uzbak, in., to yrs, Mawlawi (important religious teacher).

44. Aq Kupruk (Balkh), Tajik Sayid, f., 75 yrs, farmer's widow, nonliterate; Panjsher (Kapisa), Tajik, m., 40 yrs, mullah, non-literate.

45. Kabul (Kabul), Kabuli), m., 30 yrs, professor. See C. S. Nott (trans.), Conference of the Birds (London, 1967); also paraphrased by FitzGerald, The Bird Parliament.

46. Herat (Herat), Herati, m., 6o yrs, scholar. See also R. Curzon, Visits to Munasteries in the Levant (London, 1916), pp. 180-5, for an Egyptian version of the same tale.

47. Gaster, op. cit., p. 229; Kunstmann, op. cit., p. 8.

48. Aq Kupruk (Bolkh), Trajik Sayid, m., 15 yrs, farmer/schoolboy, as told to hin by his grandmother.

49. Bazarak, I'anjsher (Kapisa), Tajik, m., 40 yrs, mullah, non-literate; the account from Landey (Hilmand) began with "The Sulaimanai murg was the cleverest of all King Solomon's birds'. 'The Qasas al-Anbia equates the hoopoc's wisdom with its ability to detect springs.

50. Dulana, Panjsher (Kapisa), Tajik, m., 25 yrs, farmer, non-literate.

51. Aq Kupruk (Balkh), Tajik Sayid, f., 75 yrs, farmer's widow, nonliterate.

52. Ibid.

53. Bazarak, Panjsher (Kapisa), Tajik, m., 40 yrs, mullah, non-literate.

54. Said Qala (Kandahar), Pushtun, m., 40 yrs, farmer, non-literate.

55. Badwan (Kandahar), Pushtun, m., 70 yrs, farmer, non-literate.

56. Gaster, op. cit., p. 160.

57. Ali Shah, Sirdar Ikbal, Afghanistan of the Afghans (London, 1928), p. 110.

58. Landey (Hilmand).

59. Sokhta (Balkh).

6o. Landey (Hilmand), Baret Pushtun, m., 35 yrs, nomad, non-literate. Collected by A. R. Palwal.

61. In the Ghazni area bald men are jokingly referred to as hoopoes (A. S. Shalizi).

62. Herat, Herat, 60 yrs, scholar, historian and artist, the late Fikri Seljuki who is very deeply missed.

63. Again describing the mannerism of bobbing its head up and down.

64. Shorawak (Kandahar), Ghilzai Pushtun, 40 yrs, nomad, non-literate. These groups travel between Shorowak and Ghazni. Collected by A. R. Palwal.

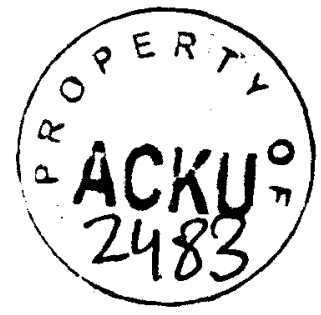

